\title{
Materiële normering van personenschade
}

\author{
$M r . d r . J . E$. van de $B u n t^{*}$
}

\section{Inleiding}

Materiële normering van personenschade is een belangrijk the$\mathrm{ma}$ in het Nederlandse schadevergoedingsrecht. ${ }^{1}$ Deze vorm van normering komt in beeld als een concrete wijze van begroting van schade lastig, zo niet onmogelijk is. ${ }^{2}$ Dat er hard aan normering is gewerkt door de branche blijkt uit het grote aantal richtlijnen dat de afgelopen vijftien jaar door De Letselschade Raad is opgesteld. ${ }^{3}$ Afgelopen najaar startte een denktank waarin vertegenwoordigers van de letselschadebranche, de rechtspraak en de wetenschap zitting hebben. ${ }^{4}$ Deze denktank zal trachten tot een nieuwe richtlijn voor het bepalen van de omvang van smartengeld te komen..$^{5} \mathrm{Er}$ is bovendien een wetsvoorstel aanhangig voor de vergoeding van genormeerde affectieschade. ${ }^{6}$ Ook in de rechtspraak zijn normen voor begroting van personenschade neergelegd. ${ }^{7}$ Het wetenschappelijk onderzoek naar normering heeft in deze periode evenmin stilgestaan en heeft geleid tot nieuwe inzichten. ${ }^{8}$

* Mr. dr. J.E. van de Bunt is zelfstandig onderzoeker te Den Haag en docent Moot Court aan de Universiteit Leiden. De auteur dankt mr. dr. Iris Houben en mr. Jeroen Quakkelaar voor hun commentaar op een eerdere versie van dit artikel.

1. Naast materiële bestaat er ook procedurele normering voor de afwikkeling van personenschade. Ik beperk mij in dit artikel tot materiële normering van personenschade.

2. Zo A.J. Akkermans, Normering van personenschade: een inleidend commentaar, TVP 2002, p. 101-102.

3. Vgl. www.deletselschaderaad.nl. De Letselschade Raad heette voor 1 januari 2009 het Nederlands Platform Personenschade. Dat werd opgericht in 1998.

4. Zo blijkt uit een bericht van 10 juni 2016: stichtingpiv.nl/wp-content/ uploads/2016/06/16-06-05-Oprichting-denktank-Smartengeld.pdf.

5. Daar worden al langer pogingen toe ondernomen, zo blijkt uit een eerder persbericht van De Letselschade Raad van 15 januari 2014: Nieuwe berekening smartengeld in de maak, te raadplegen via: www. deletselschaderaad.

6. Zie wetsvoorstel 34257, dat thans bij de Tweede Kamer voorligt.

7. Vgl. gemiddelde kosten van opvoeding in het Wrongful birth-arrest: HR 21 februari 1997, NJ 1999/145. Maximaal de professionele kosten van zorg als ouders voor hun ernstig gewonde kind zorgen: HR 28 mei 1999, NJ 1999/564 m.nt. A.R. Bloembergen. Vergoeding van kosten van huishoudelijke hulp: HR 5 december 2008, NJ 2009/387 m.nt. J.B.M. Vranken.

8. J.E. van de Bunt, Het rampenfonds (diss. Leiden), Deventer: Kluwer 2016; E. Engelhard \& R. Rijnhout, Een regeling voor personenschade door rampen, Den Haag: Boom juridisch 2015; J.D.W.E. Mulder, Compensation: The Victim's Perspective (diss. Tilburg), Oisterwijk: Wolf Legal Publishers 2013; R.M.E. Huver, K.A.P.C. van Wees, A.J. Akkermans \& N.A. Elbers, Slachtoffers en aansprakelijkheid. Een onderzoek naar behoeften, verwachtingen en ervaringen van slachtoffers en hun naasten met betrekking tot het civiele aansprakelijkheidsrecht. Deel I, Terreinverkenning (WODC-rapport), Den Haag: WODC 2007.
Bij een bezinning op deze normering van personenschade rijzen verschillende vragen. Wat houdt normering precies in? Wat vormde de aanleiding voor de normering? Welke nieuwe wetenschappelijke inzichten zijn er met betrekking tot normering? Welk punt is thans bereikt op het gebied van normering van personenschade? Is verdere normering mogelijk?

In dit artikel staat centraal wat de stand van zaken is met betrekking tot normering van personenschade en op welke wijze normering verder kan worden vormgegeven. Het artikel vangt aan met een toelichting op het begrip normering van personenschade (par. 2). Dan volgt aandacht voor de aanleiding tot normering (par. 3). Nieuwe wetenschappelijke inzichten rondom normering worden in paragraaf 4 besproken. In paragraaf 5 wordt de stand van zaken betreffende normering van personenschade uiteengezet. Vervolgens wordt een scenario voor de verre toekomst geschetst: het hanteren van allinbedragen (par. 6). In de conclusie (par. 7) zet ik uiteen dat de tendens om te normeren nog lang niet ten einde gekomen is, maar dat het lang wachten zal zijn voor er draagvlak is voor normering door middel van het hanteren van all-inbedragen.

\section{Het begrip normering}

Onder normering van schade wordt wel verstaan het gebruik van een standaard voor een grote groep van gelijke of gelijksoortige gevallen. ${ }^{9}$ Dergelijke vormen van normering zijn terug te vinden bij de schadebegroting van personenschade in de wet, ${ }^{10}$ in jurisprudentie ${ }^{11}$ en in richtlijnen van De Letselschade Raad.

Er kunnen twee soorten normering worden onderscheiden. Normering kan ten eerste bestaan uit het hanteren van gestandaardiseerde bedragen voor personenschade. Standaardbedragen zijn te vinden in de vaststellingsovereenkomst inzake de DES-dochters, die de rechter collectief verbindend verklaarde

9. S.D. Lindenbergh, Abstracties bij de vaststelling van schade, in: Abstracte schadeberekening (Preadviezen VASR), Deventer: Kluwer 2013, par. 4.1 .

10. Art. 6:119 BW bevat het recht op vergoeding van wettelijke rente en als het wetsvoorstel affectieschade wordt goedgekeurd, zullen art. 6:107 en 6:108 BW in de toekomst een recht op vergoeding van affectieschade gaan bevatten.

11. Zie HR 21 februari 1997, NJ 1999/145; HR 28 mei 1999, NJ 1999/564 m.nt. A.R. Bloembergen; HR 5 december 2008, NJ 2009/387 m.nt. J.B.M. Vranken. 
ingevolge art. 7:907 van het Burgerlijk Wetboek (BW). ${ }^{12}$ De bedragen die op grond van die overeenkomst aan de DESdochters werden toegekend, verschilden naargelang de aandoening die de DES-dochter in kwestie onder de leden had. Tevens zijn er standaardbedragen voor de vergoeding van affectieschade opgenomen in een wetsvoorstel dat nu aanhangig is. ${ }^{13}$

Ten tweede kan normering bestaan uit het gebruik van een standaardmethode om de schade te berekenen. Denk daarbij bijvoorbeeld aan een vast bedrag per kilometer voor reizen met de auto, neergelegd in een richtlijn, ${ }^{14}$ of aan de vergoeding voor vertraging in de betaling van een geldsom: de wettelijke rente (art. 6:119 BW). Dat zijn eenvoudige vormen van het gebruik van een standaardmethode. Een complexere wijze van het gebruik van een standaardmethode bestaat in de vorm van de richtlijn overlijdensschade. ${ }^{15} \mathrm{Om}$ de overlijdensschade te berekenen wordt het netto consumptief inkomen tot uitgangspunt genomen, dan worden er bepaalde posten afgetrokken en andere bij opgeteld.

Bij aansprakelijkheid is de dader schadeplichtig. Welke schade moet er worden vergoed door de dader? De omvang van de schade wordt bepaald door een vergelijking van de toestand zoals deze nu is met de toestand zoals die (vermoedelijk) zou zijn geweest indien het schadeveroorzakende feit niet zou hebben plaatsgevonden. ${ }^{16}$ De schade die een slachtoffer als gevolg van een bepaalde gebeurtenis heeft geleden, dient dan volledig te worden vergoed. Dit heeft te gelden als leidend beginsel van het schadevergoedingsrecht. ${ }^{17}$ Het uitgangspunt is dat de geleden schade concreet begroot wordt en dat de schadevergoeding bij uitzondering abstract begroot wordt. ${ }^{18}$ Abstrahering vindt plaats om redenen van doelmatigheid of omdat het lastig is om de schade concreet te begroten. ${ }^{19}$ Abstrahering en normering liggen dicht bij elkaar. ${ }^{20} \mathrm{Om}$ de standaard te vinden wordt het gangbare, het gemeenschappelijke of het normale tot uitgangspunt genomen en wordt er geabstraheerd van één of meer van de specifieke omstandigheden van het geval. ${ }^{21}$

De wet geeft ruimte voor (de ontwikkeling van) normering bij de begroting van schade. Art. 6:97 BW bepaalt dat de rechter de schade begroot op de wijze die het meest met de aard ervan in overeenstemming is. Kan de schade niet nauwkeurig wor-

12. Zie Hof Amsterdam 1 juni 2006, ECLI:NL:GHAMS:2006:AX6440.

13. Zie wetsvoorstel 34257, dat thans bij de Tweede Kamer voorligt.

14. Vgl. de Richtlijn Kilometervergoeding van De Letselschade Raad: www. deletselschaderaad.nl/richtlijnen/kilometervergoeding. De Letselschade Raad heeft meer van dergelijke richtlijnen vastgesteld. Zie www. deletselschaderaad.nl.

15. Vgl. de Richtlijn Rekenmodel Overlijdensschade van De Letselschade Raad: www.deletselschaderaad.nl/richtlijnen/rekenmodel-overlijdens schade.

16. Asser/Hartkamp \& Sieburgh 6-II 2013/31.

17. Zie bijv. J. Spier e.a., Verbintenissen uit de wet en schadevergoeding, Deventer: Wolters Kluwer 2015, p. 243.

18. Zie bijv. Spier e.a. 2015, p. 261-262.

19. Zie bijv. Spier e.a. 2015, p. 262-264.

20. Zo ook Lindenbergh 2013, par. 4.1.

21. Ibid. den bepaald, dan moet zij worden geschat. ${ }^{22}$ In de parlementaire geschiedenis wordt over art. 6:97 BW geschreven dat dit een wettelijke basis beoogt te geven aan 'abstracte en andere wijzen van schadebegroting. ${ }^{23}$ Vooral personenschade die in de toekomst wordt geleden, zoals verlies van arbeidscapaciteit, kan lastig te bepalen zijn. ${ }^{24}$ Normering van de wijze van berekening kan dan houvast geven. Maar ook als de schade al wel geleden is, kan normering de rechter te hulp schieten. Denk aan de vergoeding voor huishoudelijke hulp bij letsel als er geen concrete kosten zijn gemaakt omdat de hulp is geboden door de naasten van het slachtoffer. ${ }^{25}$ Ook dan kan normering een richtsnoer bieden voor begroting van de schade.

De verschillende bronnen van normering, de wet, ${ }^{26}$ jurisprudentie en richtlijnen, hebben niet allemaal dezelfde kracht om te verbinden. Normerende wettelijke bepalingen moeten worden gevolgd en hebben in de hiërarchie de sterkste verbindende kracht. Normering van de Hoge Raad zal in beginsel moeten worden gevolgd totdat de Hoge Raad anders beslist. Die normering heeft dus ook een sterke verbindende kracht, zij het minder dan wetgeving. De richtlijnen van De Letselschade Raad hebben de minst bindende kracht. Zij binden in elk geval de achterban, de brancheorganisaties die de richtlijn met elkaar hebben opgesteld. Dit zijn de ANWB, de Federatie van Slachtofferorganisaties, het Nederlands Instituut van Register Experts, de branchevereniging Nederlandse Letselschade Experts, het Personenschade Instituut Verzekeraars, het Verbond van Verzekeraars en de Vereniging van Letselschade Advocaten. ${ }^{27}$

Er is weinig rechtspraak waarin de richtlijnen een rol spelen. ${ }^{28}$ Dat komt ook doordat de meeste letselschadezaken, naar schatting 95-99\% buitengerechtelijk, dus buiten de rechter om, worden afgedaan. ${ }^{29}$ De rechter is niet gebonden aan de richtlijnen, maar als partijen beide naar de richtlijn verwijzen, zal de rechter hoogstwaarschijnlijk de richtlijn volgen. Ook

22. Aldus de tweede volzin van art. 6:97 BW. Zie hierover bijv. S.D. Lindenbergh, in: GS Schadevergoeding, Deventer: Wolters Kluwer (losbl.), art. $6: 97$, aant. 19. In cassatie kan overigens alleen worden getoetst of de rechter blijk heeft gegeven van een onjuiste rechtsopvatting omtrent het begrip schade of ter zake van de wijze van begroting van de schade. Zo blijkt ook uit HR 18 april 1986, ECLI:NL:HR:1986:AC9304, NJ 1986/567 m.nt. W.C.L. van der Grinten.

23. Zie MvA II, PG Boek 6, p. 339.

24. Zie hierover meer in par. 5 van dit artikel.

25. HR 5 december 2008, ECLI:NL:HR:2008:BE9998, NJ 2009/387.

26. Art. 6:119 BW bevat het recht op vergoeding van wettelijke rente en als het wetsvoorstel affectieschade wordt goedgekeurd, zullen art. 6:107 en 6:108 BW in de toekomst een recht op vergoeding van affectieschade gaan bevatten.

27. Aangetekend moet worden dat de Vereniging van Advocaten voor Slachtoffers van Personenschade zich niet gebonden acht aan de richtlijnen. $\mathrm{Zij}$ wil de vrijheid hebben om in individuele gevallen af te wijken van de richtlijnen als de werkelijk geleden schade hoger is. Bij een juiste toepassing van de richtlijnen zou dat niet nodig moeten zijn, omdat de richtlijnen ruimte geven om af te wijken als de schade hoger is (zie ook hierna).

28. Een zoekactie in rechtspraak.nl levert een dertigtal uitspraken op.

29. Zo W.C.T. Weterings, Mediation en de afwikkeling van personenschadeclaims, TvM 2006, p. 2-8, i.h.b. p. 2. 
wanneer slechts een van de partijen ernaar verwijst, heeft de rechter - afhankelijk van de stellingen van de wederpartij - de vrijheid de richtlijn als hulpmiddel te gebruiken om de schade te begroten. ${ }^{30}$

De richtlijnen van De Letselschade Raad moeten worden opgevat als een minimumnorm - zoals ook abstracte schadeberekening. ${ }^{31}$ De achtergrond van normering is dan de doelmatigheid. ${ }^{32}$ Het uitgangspunt van volledige schadevergoeding speelt daarbij een rol. Is er aantoonbaar meer schade geleden, dan moet die worden vergoed. Bij schade die lastig op geld te waarderen is, zoals het bieden van huishoudelijke hulp of mantelzorg door familie of kennissen, zal een hoger bedrag dan de norm niet kunnen worden aangetoond. Daar is de reden van normering gelegen in de billijkheid. ${ }^{33} \mathrm{Bij}$ andere vormen van normering dan door richtlijnen - door wet of rechtspraak - is het genormeerde bedrag doorgaans tevens het maximumbedrag dat vergoed wordt. Dan leggen billijkheidsof doelmatigheidsoverwegingen kennelijk meer gewicht in de schaal dan het beginsel van volledige schadevergoeding.

De verschillende richtlijnen normeren de schadeposten. Er moeten feiten worden gesteld en zo nodig bewezen, die aanleiding geven tot het bestaan van een bepaalde schadepost. De wijze van schadeberekening of de standaardbedragen uit de richtlijnen geven dan recht op een bepaald bedrag. Een verdere onderbouwing is niet nodig - daarin ligt het voordeel voor het slachtoffer van normering door de richtlijn. Is de geleden schade in werkelijkheid hoger dan de richtlijn, dan heeft het slachtoffer recht op dat hogere bedrag, als hij die hogere schade tenminste kan aantonen. ${ }^{34}$

\section{Aanleiding tot normering}

Ongeveer vijftien jaar geleden belandde normering van personenschade op de wetenschappelijke agenda in Nederland. Binnen het Centrum voor Aansprakelijkheidsrecht van Tilburg University begon in die tijd aandacht te ontstaan voor materiele en procedurele normering met verschillende publicaties en expertmeetings. ${ }^{35}$ Materiële normering gaat over de normen die te maken hebben met de hoogte van het schadebedrag; we zagen dat dit standaardbedragen kunnen zijn of een standaardmethode voor de berekening van schade kan inhouden. Procedurele normering gaat daarentegen over de stroomlij-

30. Zo doet bijv. Rb. Rotterdam 19 maart 2014, ECLI:NL:RBROT: 2014:4452.

31. Zie Spier e.a. 2015, p. 261-262.

32. Vgl. T. Hartlief, Verbintenissen uit de wet en schadevergoeding, Deventer: Wolters Kluwer 2015, p. 264.

33. Ibid

34. Zie de rubriek Veel gestelde vragen over Richtlijnen op de website www. deletselschaderaad.nl.

35. Zie bijv. I. Giesen, Normering van schadevergoeding in Engeland: een les voor Nederland?, NJB 2001, p. 120-123; I. Giesen, P. Kamminga \& J.M. Barendrecht, Normering van schadevergoeding voor arbeidsongevallen en beroepsziekten: over draagvlak, differentiatie en smartengeld, in: M. Faure \& T. Hartlief (red.), Schade door arbeidsongevallen en nieuwe beroepsziekten, Den Haag: Boom Juridische uitgevers 2002, p. 131-165. ning van het proces van schadeafwikkeling. Aan de Vrije Universiteit kwam er onderzoek naar de stroomlijning van het medische traject in de aansprakelijkheidsprocedure - dit betreft een stap in het proces van schadeafwikkeling en dus procedurele normering. ${ }^{36}$ In een themanummer van het Tijdschrift voor Vergoeding Personenschade probeerden wetenschappers een aanzet te geven tot een brede discussie over de normering van personenschade. ${ }^{37}$ Een lans werd gebroken voor niet-bindende normen, naar het Belgisch voorbeeld van de indicatieve tabel. ${ }^{38}$

Deze Belgische indicatieve tabel werd vernieuwd in 2001 en vormde mede de aanleiding tot de aandacht in Nederland voor normering. ${ }^{39}$ De tabel werd opgesteld door rechtersverenigingen en biedt een integrale visie op de berekening van de verschillende lastig te berekenen posten van personenschade. Inmiddels is de meest recente versie van de tabel in 2012 opgesteld. ${ }^{40}$ De indicatieve tabel bevat de te vergoeden schadeposten en bepaalt voor die schadeposten wat de standaardbedragen zijn of wat de standaardwijze van berekening is. Afwijking van de tabel is mogelijk als het slachtoffer het bestaan en de omvang van een hogere schade kan onderbouwen. ${ }^{41}$ De tabel bindt de rechter niet; de tabel dient uitdrukkelijk als hulpmiddel.

Ook in Nederland zou het mogelijk moeten zijn meer normering tot stand te brengen voor posten die moeilijk concreet te begroten zijn, zo werd destijds betoogd. ${ }^{42}$ Een niet-bindende vorm zou het meest haalbaar zijn. Niet alleen in de wetenschap, maar ook in de praktijk bleek er aanleiding tot normering. Het Nederlands Platform Personenschade, dat in 1998 werd opgericht (en later is opgegaan in De Letselschade Raad), is in diezelfde periode aan de slag gegaan met verschillende brancheorganisaties om normering voor verschillende schadeposten te ontwikkelen in de vorm van de achterban bindende richtlijnen.

Van normering werden tal van voordelen verwacht. Het voorkomen van discussie, ${ }^{43}$ het bieden van een snelle gerechtelijke of buitengerechtelijke procedure, het bereiken van een overzichtelijke en beheersbare schadelast, het bewerkstelligen van meer eenheid van rechtspraak, het verlichten van de taak van

36. Zie A.J. Akkermans \& A.J. Van, De medische expertise bij personenschade: knelpunten en mogelijke oplossingen, TVP 2002, p. 57-61; A.J. Akkermans, Verbeterde vraagstelling voor medische expertises. Een inventarisatie van knelpunten, verbeteringen, en mogelijke verdere aanpak, TVP 2005, p. 69-80.

37. Themanummer TVP 2002, afl. 4, 'Normering van schadevergoeding'.

38. Zie A.J. Akkermans, Normering van personenschade: een inleidend commentaar, TVP 2002, p. 101-102; I. Giesen, De 'bindendheid' van normen bij normering van schadevergoeding, TVP 2002, p. 127-129.

39. Zie de bespreking: B. de Temmerman \& E. de Kezel, Normering in België: de indicatieve tabel, TVP 2002, p. 101-114.

40. Zie J.-L. Desmecht, Th. Papart \& W. Peeters (red.), Indicatieve tabel 2012, Brugge: die Keure 2012.

41. De Temmerman \& De Kezel 2002, p. 113.

42. Akkermans 2002, p. 102.

43. Akkermans 2002, p. 101. 
de rechter en het geven van prikkels tot schikking. ${ }^{44}$ Er zijn ook enkele nadelen benoemd: bijvoorbeeld onvoldoende draagvlak voor de ontwikkelde normen of principiële tegenstand tegen het afwijken van concrete schadebegroting. ${ }^{45}$ In dat laatste geval zal nu eens het slachtoffer (als er minder dan de werkelijke schade vergoed wordt), dan weer de dader (als er meer dan de werkelijke schade vergoed wordt) ontevreden kunnen zijn bij abstracte, genormeerde begroting van schade. $\mathrm{Al}$ met al hadden de voordelen van normering ruimschoots de overhand.

\section{Huidige praktijk normering personenschade en mogelijkheden tot uitbreiding}

In de huidige praktijk van de personenschade wordt normering al voor een groot aantal schadeposten toegepast. Ik zal de verschillende mogelijke schadeposten die voor vergoeding in aanmerking komen benoemen, de daarbij al behorende normering kenschetsen en eventueel de mogelijkheden tot uitbreiding van normering beschrijven. Eerst komt letselschade aan de beurt, daarna volgt overlijdensschade.

\subsection{Letselschade}

Bij letselschade komen verschillende posten voor vergoeding in aanmerking. Voor de berekening van de grootste post, verlies van arbeidscapaciteit voor de rest van het leven van het slachtoffer, bestaat speciale software: in de praktijk wordt het Audalet-programma of het RekenProgramma gebruikt. ${ }^{46}$ Deze programma's nemen het fictieve carrièreverloop zonder ongeval en trekken daarvan af de resterende verdiencapaciteit ná het ongeval. De inhoud van de programma's is tot stand gekomen door overleg tussen aansprakelijkheidsverzekeraars en vertegenwoordigers van de slachtoffers. ${ }^{47}$ Door een standaardwijze van berekening te nemen waar draagvlak voor bestaat, wordt voorkomen dat partijen het oneens zijn. De discussie gaat dan niet over de uitkomst van het programma, maar over de uitgangspunten. Kunnen partijen de uitgangspunten onderschrijven, dan zullen ze ook de uitkomst van de berekening aanvaarden. ${ }^{48}$ De programma's bestaan uit een kern en een schil. ${ }^{49}$ Tot de kern behoren standaardregels gebaseerd op wetgeving en jurisprudentie, waar verzekeraars en slachtoffervertegenwoordigers het unaniem over eens zijn. Die regels worden dus altijd gevolgd bij een berekening. Tot de schil behoren regels die optioneel gekozen kunnen worden, waarover verzekeraars en slachtoffervertegenwoordigers het in meerderheid eens zijn. De berekening volgens de kern is dus

44. De Temmerman \& De Kezel 2002, p. 103-104.

45. De Temmerman \& De Kezel 2002, p. 111.

46. Vgl. over deze rekenstandaard D.J. ten Boom, Normering in de berekening van personenschade: Audalet inside, TVP 2002, p. 121-124 en D.J. ten Boom, De X-factor in de berekening van toekomstschade, mysterieus of meetbaar, TVP 2006, p. 76-81. Ook in de rechtspraak komt het Audalet-rekenprogramma terug. Bijv. in de conclusie van A-G Spier van 26 september 2014, ECLI:NL:PHR:2014:1816, par. 1.11; Rb. Breda 28 november 2012, ECLI:NL:RBBRE:2012:BY4683; HR 11 juli 2003, ECLI:NL:HR:2003:AF7884.

47. Vgl. Ten Boom 2002, p. 121.

48. Ook zo Ten Boom 2002, p. 121

49. Vgl. Ten Boom 2002, p. 121. volledig genormeerd en volgens de schil tot op zekere hoogte. Toch blijft er bij de berekening met behulp van deze programma's veel discussie mogelijk. Dat hangt samen met de benodigde invoer van gegevens in zo'n programma.

Daarbij geldt: hoe jonger het slachtoffer is, hoe lastiger het is een voorspelling te doen over de hypothetische toekomst met en zonder ongeval. Het gaat dan over de kansen in het leven. Er kan dan immers nog heel veel gebeuren, zowel in positieve als in negatieve zin. Om te beginnen het carrièreverloop van het slachtoffer: zou dat succesvol of minder succesvol zijn geweest zonder de schadeveroorzakende gebeurtenis? Daar ligt nog een kans voor normering, in de zin dat er een groot aantal standaardcarrièreperspectieven kan worden ontwikkeld voor verschillende beroepen. ${ }^{50}$ In de feiten kan dan aanleiding worden gevonden voor bijstelling naar boven of naar beneden. Dit lijkt in overeenstemming met een uitspraak van het Hof Arnhem-Leeuwarden, waarin het hof overweegt dat bij de begroting van het fictieve carrièreverloop algemene statistische gegevens niet doorslaggevend zijn, maar de specifieke situatie van een slachtoffer. ${ }^{51}$ Als de standaardcarrièreperspectieven voldoende uitgewerkt zijn, zullen zij aanknopen bij de specifieke situatie van het slachtoffer en leiden tot minder bijstelling naar boven en naar beneden, zodat partijen in een geschil elkaar sneller zullen vinden.

Ook zal in het carrièreverloop worden meegenomen of het slachtoffer (tijdelijk) minder zou zijn gaan werken als hij of zij kinderen krijgt en op welk moment het slachtoffer met pensioen zou zijn gegaan. Van het fictieve carrièreverloop moet worden afgetrokken inwat de resterende verdiencapaciteit is. In de praktijk is de resterende verdiencapaciteit een belangrijk twistpunt. Nadat partijen een bedrag zijn overeengekomen en dit aftrekken van het fictieve carrièreverloop, moet dit nog worden gekapitaliseerd aan de hand van de renteopbrengst en de inflatie (tezamen de rekenrente genoemd) en de sterftekans. Ook die schijnbaar objectieve gegevens leiden in de praktijk tot discussie; zij kunnen evenwel goed genormeerd worden. Op dit moment wordt door De Letselschade Raad gewerkt aan een richtlijn voor de rekenrente.

Een andere standaardpost bij personenschade wordt gevormd door de ziektekosten. Deze kosten laten zich relatief gemakkelijk concreet begroten: de al gemaakte kosten en een inschatting van de nog te maken kosten leiden tot de door de dader te vergoeden schade. ${ }^{52}$

Voor verschillende kosten als huishoudelijke bulp, daggeld als tegemoetkoming voor de kosten in het ziekenhuis doorgebracht, studievertraging, kilometervergoeding en verlies aan zelfwerk-

50. Zie hierover ook Weterings 2008, p. 133-157.

51. Hof Arnhem-Leeuwarden 5 augustus 2014, ECLI:NL:GHARL: 2014:6223, r.o. 2.6.

52. Deze medische kosten worden doorgaans grotendeels vergoed door de zorgverzekeraar van het slachtoffer. De verzekeraar kan vervolgens regres op de dader nemen (op grond van art. 7:962 BW). 
zaamheid bestaan inmiddels richtlijnen van De Letselschade Raad. Uit deze richtlijnen volgen normen voor vergoeding. ${ }^{53}$ Wanneer aansluiting bij die norm wordt gezocht, hoeft de schade niet nader onderbouwd te worden. Wel moet vast komen te staan dat een bepaalde schadepost ook daadwerkelijk geleden is of wordt. Als kan worden aangetoond dat de werkelijke schade hoger ligt, kan de schade - in afwijking van de richtlijn - naar boven worden bijgesteld. Volgens de Richtlijn Huishoudelijke Hulp bijvoorbeeld worden voor mantelzorg door familie, vrienden en kennissen voor de eerste drie maanden na een ongeval standaardbedragen per week aan huishoudelijke hulp gehanteerd en worden na drie maanden de uren die nodig zijn voor een normbedrag van $€ 9$ per uur vergoed. ${ }^{54}$ De richtlijn sluit aan bij een uitspraak van de Hoge Raad uit 2008, waarin de wijze van schadebegroting wordt bepaald voor vergoeding van huishoudelijke hulp in geval van letsel. ${ }^{55}$ Wanneer het slachtoffer niet langer huishoudelijk werk kan verrichten en dit werk normaal gesproken door professionals zou worden overgenomen, bestaat recht op vergoeding van de abstract berekende kosten van huishoudelijke hulp - dus ook als die kosten niet daadwerkelijk worden gemaakt. Over de mate van beperking van het slachtoffer ten aanzien van huishoudelijk werk en de periode van hulp die nodig is om het huishouden draaiend te houden, kan ook bij toepassing van de richtlijn nog wel discussie ontstaan.

Waar het gaat om immateriële schadevergoeding, vergoeding voor verdriet en leed, biedt art. 6:106 BW de grondslag voor een naar billijkheid vast te stellen schadevergoeding. Van de Hoge Raad moet de rechter ook kijken naar wat door de rechter is toegekend in vergelijkbare gevallen. ${ }^{56}$ De rechter gebruikt daarbij het Smartengeldboek. ${ }^{57}$ Daarin is het letsel in vijf hoofdgroepen ingedeeld en vervolgens gerubriceerd naar de aard van het letsel per casus. De rechter kijkt naar een geval waar zijn dossier op lijkt en gaat dan afwegen of hij in positieve of negatieve zin factoren kan aanwijzen die tot meer of minder schadevergoeding moeten leiden. ${ }^{58}$ Over de ontwikkeling van de smartengeldbedragen bestaat in de praktijk onvrede. De bedragen zouden met name te laag zijn en achterblijven bij de bedragen in de ons omringende landen. ${ }^{59}$ Er zijn al uitspraken

53. De verschillende richtlijnen zijn te raadplegen via: www deletselschaderaad.nl/richtlijnen.

54. Zie de Richtlijn Huishoudelijke Hulp, te raadplegen via: www. deletselschaderaad.nl.

55. HR 5 december 2008, ECLI:NL:HR:2008:BE9998, NJ 2009/387.

56. HR 17 november 2000, NJ 2001/215 m.nt. A.R. Bloembergen, r.o. 3.2. Eerder al, maar iets minder dwingend: HR 8 juli 1992, NJ 1992/714.

57. Zie voor de online toegang van het Smartengeldboek de website www. smartengeld.nl. Oorspronkelijk was het Smartengeldboek een speciale uitgave van het tijdschrift Verkeersrecht. Toen heette het de Smartengeldgids. Het is ook nog steeds van de ANWB, alleen niet meer gekoppeld aan Verkeersrecht (ook van de ANWB).

58. G. de Groot, Smartengeld en de rechter, VR 2013, p. 277-282.

59. C.C. van Dam, Begroting en verhoging van smartengeld. Wat Nederland kan leren van Engelse Guidelines en Duitse grondrechten, VR 2013, p. 256-268. van lagere rechters geweest die de bedragen uit het Smartengeldboek daarom verhogen. ${ }^{60}$

Voor licht letsel geldt momenteel een richtlijn van De Letselschade Raad; deze is overigens gebaseerd op gevallen uit het Smartengeldboek. ${ }^{61}$ In die richtlijn zijn drie categorieën opgenomen, bijvoorbeeld van $€ 0$ tot $€ 825$ voor oppervlakkig en beperkt letsel met een herstelperiode van ongeveer twee maanden. Elke categorie kent een bandbreedte waarbinnen partijen het eens zullen moeten worden. Een dergelijke bandbreedte geeft wel duidelijk aan waaraan gedacht kan worden.

Voor zwaarder letsel is het Smartengeldboek beschikbaar. Voor het bepalen van een bedrag aan smartengeld zal de rechter kunnen aanknopen bij het letsel dat het meest overeenkomt met dat van het slachtoffer. ${ }^{62}$ Een denktank, waarin brancheorganisaties, de rechtspraak en de wetenschap samenkomen, is net begonnen met het formuleren van een richtlijn voor smartengeld voor zwaardere gevallen van letselschade. Gespeculeerd kan worden over de inhoud van de toekomstige richtlijn. Wellicht zou ook die zwaardere immateriële schade in een aantal categorieën kunnen worden ingedeeld, waarna bandbreedtes kunnen worden aangehouden.

In de toekomst zal waarschijnlijk eveneens de immateriële schade, affectieschade, van naasten kunnen worden gevorderd; een daartoe strekkend wetsvoorstel wordt thans in de Tweede Kamer behandeld. ${ }^{63}$ Deze schade zal genormeerd zijn tot vaste bedragen tussen $€ 12.500$ en $€ 17.500$ voor een tweetal categorieën schade: ernstig en blijvend letsel en ernstig en blijvend letsel door een misdrijf. Er is voorzien in een vaste kring van gerechtigden, een achttal in totaal. Er worden dus standaardbedragen gehanteerd. ${ }^{64}$ Wat onder ernstig en blijvend letsel moet worden verstaan, moet dan nog bij algemene maatregel van bestuur worden vastgesteld, waarschijnlijk nadat daaraan door de rechtspraak invulling is gegeven. ${ }^{65}$

\subsection{Overlijdensschade}

Bij overlijdensschade komen de posten, waar art. 6:108 BW recht op geeft, voor vergoeding aan de nabestaanden in aanmerking. Daaronder valt het levensonderhoud waar het slachtoffer in voorzag en de bulp in natura (zoals de kosten voor

60. Zo bijv. Rb. Midden-Nederland 14 september 2016, ECLI:NL:RBMNE:2016:5346; Rb. Gelderland 11 november 2015, ECLI:NL:RBGEL:2015:6968, JA 2016/10 m.nt. M.E. Franke; Hof Arnhem-Leeuwarden 5 augustus 2014, ECLI:NL:GHARL:2014:6223, JA 2014/124.

61. Zie www.deletselschaderaad.nl.

62. Zie voor de online toegang de website: www.smartengeld.nl.

63. Zie Kamerstukken II 2014/15, 34257, 3, p. 19 (MvT). Eerder is een wetsvoorstel (28781) verworpen, dat te weinig differentieerde tussen de gerechtigden onderling en de categorieën schade: Handelingen I 2009/10, 23, p. 1013-1014.

64. Zie Kamerstukken II 2014/15, 34257, 3, p. 20 (MvT).

65. Zo luidt de toelichting op het nieuw voorgestelde art. 6:107 lid 3 BW. Zie Kamerstukken II 2014/15, 34257, 3, p. 20 (MvT). 
oppas, huishoudelijke hulp en klussen $)^{66}$ die het overleden slachtoffer voor zijn rekening nam (vergelijk art. 6:108 lid 1 BW). Sinds 2014 bestaat hiervoor het rekenmodel overlijdensschade, dat door De Letselschade Raad tot richtlijn is gemaakt. ${ }^{67}$ Het nettogezinsinkomen voor overlijden minus de weggevallen (genormeerde) uitgaven van de overledene vormt de behoefte van het achtergebleven gezin. Daarvan worden afgetrokken het nettogezinsinkomen na overlijden en de extra weggevallen uitgaven, en opgeteld de extra bijkomende kosten voor de weggevallen hulp in natura. De uitkomst is de schade van het gezin op jaarbasis. ${ }^{68} \mathrm{Als}$ een belangrijke reden om deze schadepost opnieuw te normeren werd genoemd dat de oude berekeningswijze bijzonder ingewikkeld was en niet uit te leggen aan de nabestaande(n), waardoor veel discussie kon ontstaan. $^{69}$

Ook kan degene te wiens laste de begrafeniskosten, in de wet de kosten van lijkbezorging genoemd (art. 6:108 lid 2 BW), zijn gekomen deze vorderen van de dader, voor zover die kosten in overeenstemming zijn met de omstandigheden van het slachtoffer. Naar de letter van de wet kan er voor een overleden slachtoffer afhankelijk van zijn sociale status en zijn religieuze of culturele achtergrond meer of minder te vorderen zijn. Het betreft de kale begrafeniskosten (kist, rouwauto, dienst en begrafenisondernemer), de bijkomende kosten (rouwadvertenties, bloemen, uitnodigingen, drankjes, versnaperingen en bedankbrieven) en verder verwijderde kosten als een grafsteen en reiskosten naar het buitenland als het slachtoffer daar begraven wordt. ${ }^{70}$ Deze post leidt in de praktijk tot weinig problemen, zodat normering ervan niet voor de hand ligt. Er kan bijvoorbeeld van een standaardbedrag van $€ 7500$ worden uitgegaan, een bedrag dat ook door het Schadefonds Gewelds-

66. Sinds HR 11 juli 2008, ECLI:NL:HR:2008:BC9365, NJ 2009/385 m.nt. J.B.M. Vranken is duidelijk dat naar de behoeftigheid in concrete zin moet worden gekeken als het gaat om art. 6:108 lid 1 aanhef en onder d BW, maar mag worden geabstraheerd van de bijdrage van een stiefouder en het feit dat ten tijde van de uitspraak geen kosten worden gemaakt. Zie ook Spier e.a. 2015, p. 323.

67. Vgl. www.deletselschaderaad.nl/richtlijnen/rekenmodel-overlijdens schade. De Richtlijn Rekenmodel Overlijdensschade staat niet op zich, maar vormt een geheel met de Notitie van de Denktank Overlijdensschade en de rapportage van het Nibud van juli 2014. Ook in de rechtspraak zijn al verwijzingen naar dit rekenmodel terug te vinden, zie bijv. Rb. Midden-Nederland 22 april 2015, ECLI:NL:RBMNE:2015:5847.

68. Hierover allen in positieve zin: J. Tiemersma \& M. de Haan, Afwikkeling overlijdensschade. Gaan nabestaanden 'over lijdensweg' voordat zij een vergoeding krijgen?, AV\&S 2015, p. 83-87, i.h.b. p. 84-85; E.J. Bakker, Oud \& nieuw in de overlijdensschade: een wisseling van de wacht, Tijdschrift Letselschade in de Praktijk 2015, p. 20-26; J. Laumen \& C. de Koning, Berekening overlijdensschade kan transparanter, De Beursbengel april 2015, p. 8-11.

69. Tiemersma \& De Haan 2015, p. 83; Bakker 2015, p. 21; Laumen \& De Koning 2015, p. 8.

70. Zie hierover A.T. Bolt, in: GS schadevergoeding, Deventer: Wolters Kluwer (losbl.), art. 6:108 BW; G.M. van Wassenaer, Hoe redelijk is, gelet op de omstandigheden van de overledene, nu werkelijk redelijk?, VR 2008, p. 310-313. misdrijven wordt gehanteerd. ${ }^{71}$ De nabestaande kan dat bedrag vorderen, tenzij de schade in werkelijkheid hoger is. In dat geval worden de meerkosten vergoed, als zij tenminste in overeenstemming zijn met de omstandigheden van het slachtoffer.

Het is de verwachting dat in de toekomst ook de affectieschade van nabestaanden als gevolg van het overlijden van een slachtoffer te vorderen zal zijn - dit volgt uit eerdergenoemd wetsvoorstel. ${ }^{72}$ Deze schade is genormeerd in vaste bedragen tussen $€ 15.000$ en $€ 20.000$ voor een tweetal categorieën schade: overlijden en overlijden door een misdrijf. ${ }^{73} \mathrm{Er}$ is voorzien in een vaste kring van gerechtigden, een achttal in totaal. Er gelden wederom standaardbedragen. ${ }^{74}$ Een eerder wetsvoorstel over de normering van affectieschade heeft het niet gehaald, omdat er kritiek was op het gebrek aan differentiatie in het voorstel. ${ }^{75}$ Het huidige wetsvoorstel komt gedeeltelijk aan die kritiek tegemoet.

\section{Nieuwe wetenschappelijke inzichten}

\subsection{Kortere procedure}

$\mathrm{Na}$ de aanzet tot normering van vijftien jaar geleden is de normering van personenschade van verschillende belangrijke posten tot stand gekomen. Zoals ik heb aangegeven in de vorige paragraaf zou die normering nog verder kunnen worden ontwikkeld. Deze voortschrijdende normering wordt ondersteund door nieuwe wetenschappelijke inzichten over normering uit mijn proefschrift over rampenfondsen. ${ }^{76}$ Deze inzichten omtrent normering van personenschade concentreren zich rondom twee voordelen: de bekorting van de procedure door normering en de verlaging van de kosten van de procedure. Normering leidt tot een kortere procedure, aangezien de tijdrovende klus van de begroting van schade in het individuele, concrete geval vervalt of wordt verlicht. Als er standaardbedragen gelden, hoeft de schade niet meer vastgesteld te worden. ${ }^{77}$ Bestaat er een standaard voor de wijze van berekening van de schade, dan leidt deze tot een invuloefening. Ook ingewikkel-

71. Zij het wel als maximumbedrag waar het Schadefonds Geweldsmisdrijven recht op geeft. Dit schadefonds keert echter een tegemoetkoming uit, die ten hoogste het bedrag van de veroorzaakte schade beloopt (art. 4 Wet schadefonds geweldsmisdrijven). Zie ook de beleidsbundel Schadefonds geweldsmisdrijven, p. 16, te raadplegen via: www. schadefonds.nl.

72. Thans is een daartoe strekkend wetsvoorstel in voorbereiding: Kamerstukken II $2014 / 15,34257,3$, p. 19 (MvT). Eerder is een wetsvoorstel (28781) verworpen, dat te weinig differentieerde tussen de gerechtigden onderling en de categorieën schade: Handelingen I 2009/10, 23, p. 1013-1014.

73. Het gaat om andere bedragen dan de vergoeding voor naasten van slachtoffers met ernstig en blijvend letsel, zie par. 4.1.

74. Zie Kamerstukken II 2014/15, 34257, 3, p. 20 (MvT).

75. Zie het dossier 28781. Zie hierover bijv. Wetsvoorstel Affectieschade gesneuveld, NJB 2010/690.

76. J.E. van de Bunt, Het rampenfonds (diss. Leiden), Deventer: Wolters Kluwer 2016. In deze paragraaf wordt gebruik gemaakt van dit proefschriftonderzoek.

77. Dat het slachtoffer schade heeft geleden, of een bepaalde schadepost heeft, moet worden gesteld en zo nodig bewezen volgens de regels van het bewijsrecht (art. $150 \mathrm{Rv}$ ). 
der vormen van normering door middel van een standaardmethode, zoals het gebruik van de Richtlijn Rekenmodel Overlijdensschade, leiden al tot een bekorting van de procedure. Was zo'n standaardmethode er niet, dan zou over de wijze van berekening al heel veel twist kunnen zijn en zouden deskundigen aangetrokken worden om de schade te berekenen. Bij voortschrijdende normering, zo is onderzocht, wordt de rol van de schade-expert of medisch deskundige kleiner (bij een eenvoudige of een ingewikkelder standaardmethode) of verdwijnt zelfs helemaal uit beeld (bij standaardbedragen) ${ }^{78}$ Dat betekent tijdwinst.

Een kortere procedure is beter voor het slachtoffer, zo valt op te maken uit onderzoek. In langdurig procederen schuilen namelijk de gevaren van secundaire victimisatie en secundaire ziektewinst. ${ }^{79}$ De reden daarvoor zou gelegen zijn in de focus van het aansprakelijkheidsrecht op het verkrijgen van een schadevergoeding en op het uitvergroten van de tegengestelde belangen van partijen in een procedure. Dit kan resulteren in zogenaamde secundaire victimisatie door de psychische belasting van het aansprakelijkheidsrecht: slachtoffers kunnen verstrikt raken in het aansprakelijkheidsrecht, wanneer zij het gevoel hebben niet gehoord te worden, telkens opnieuw hun verhaal moeten vertellen en herhaaldelijk medische onderzoeken moeten ondergaan. Daarbij speelt ook een rol dat slachtoffers geen controle denken te hebben over de procedure en de afwikkeling van de schade, en daarmee uiteindelijk ook het gevoel hebben hun leven niet meer in de hand te hebben. Naarmate de procedure langer duurt, zijn de slachtoffers minder tevreden.

Naast secundaire victimisatie bestaat onder slachtoffers en medische beroepsbeoefenaren de overtuiging dat procederen een negatief effect kan hebben op de gezondheid van slachtoffers: secundaire ziektewinst. ${ }^{80}$ Slachtoffers krijgen immers meer schadevergoeding wanneer hun ziektebeeld langer aanhoudt, er geen herstel optreedt en zij langer bij het gebeurde blijven stilstaan. ${ }^{81}$ Normering zorgt er dan voor dat het slachtoffer eerder zal herstellen; dit leidt tot lagere kosten voor de dader.

Slachtoffers die een beroep kunnen doen op het Schadefonds Geweldsmisdrijven en die de procedure als snel ervaren, zijn tevredener dan degenen die de procedure langzaam vinden, zo blijkt. ${ }^{82}$ Ook voor de slachtoffers van individuele geschillen zal dit hoogstwaarschijnlijk het geval zijn. Omdat normering leidt tot een kortere procedure, zal dat naar verwachting als effect

78. Zo blijkt ook uit normering die wordt toegepast in schadefondsen: Van de Bunt 2016, p. 201.

79. In die zin: Huver e.a. 2007, p. 40; A.J. Akkermans \& K.A.P.C. van Wees, Het letselschadeproces in therapeutisch perspectief, TVP 2007, p. 106-108.

80. Ibid.

81. Dit mag er niet toe leiden dat slachtoffers hun schadebeperkingsplicht schenden. Indien dit toch het geval is, kan de vergoedingsplicht op grond van art. 6:101 lid $1 \mathrm{BW}$ worden verminderd.

82. Dit is ongeacht de uitkomst van de procedure. Mulder 2013, p. 100. hebben dat het slachtoffer tevredener is en een betere gezondheid heeft.

\subsection{Lagere kosten}

Niet alleen wordt de procedure korter als gevolg van normering; de procedure blijkt ook goedkoper te zijn. De kosten van het aansprakelijkheidsrecht worden geschat op 25 tot $50 \%$ van de opbrengst van een geschil, al zijn ze lastig te becijferen. ${ }^{83} \mathrm{De}$ kosten van door de overheid gefinancierde schadefondsen, die een vergoeding geven voor schade waar een ander voor aansprakelijk is, zijn gemakkelijker inzichtelijk te maken. ${ }^{84}$ Onderzoek naar die kosten in een zestal schadefondsen wijst uit dat het gebruik van standaardbedragen tot de laagste uitvoeringskosten leiden (7, 13 en $31 \%$ van de uitkeringslast). De duurste fondsen (41, 46 en 53\%) baseren hun vergoeding op de concrete, werkelijk geleden schade. Wanneer een fonds ervoor kiest de fondsuitkering te baseren op de werkelijke schade, zijn daarmee extra kosten voor de uitvoering gemoeid. Waar bij het gebruik van standaardbedragen een eenvoudig beslisschema volstaat, dient bij een fondsuitkering gebaseerd op de werkelijke schade een precieze meting door deskundigen te worden verricht.

Geconstateerd kan worden dat de wijze van schadeberekening door het schadefonds een belangrijke factor is voor de hoogte van de uitvoeringskosten..$^{85}$ Betrekken we de uitkomst van het onderzoek op de begroting van personenschade van een individueel slachtoffer, dan zouden de kosten van de (buitengerechtelijke en/of gerechtelijke) procedure beduidend lager zijn als uitsluitend gekozen zou worden voor het vaststellen van de schade door middel van normering. Dit houdt in dat wordt gewerkt met standaardbedragen of met een standaardmethode van berekening, zoals bijvoorbeeld gebeurt in verschillende richtlijnen van De Letselschade Raad. ${ }^{86} \mathrm{Na}$ het vaststellen van aansprakelijkheid hoeven er minder kosten te worden gemaakt voor het bepalen van de schade. In de vorige paragraaf kwam naar voren dat nog niet alle posten bij de berekening van personenschade genormeerd zijn. Een verdere normering van bijvoorbeeld de berekening van het verlies van arbeidscapaciteit zou de kosten van de procedure verder doen dalen.

Het voordeel van de lagere kosten zou vooral de (verzekeraar van de) dader ten goede komen als er wordt geschikt. Er wor-

83. Ik heb hierover althans geen concretere cijfers kunnen vinden. Wat er beschikbaar is: W.C.T. Weterings, Vergoeding van letselschade en transactiekosten, Deventer: Tjeenk Willink 1999, en later: W.C.T. Weterings, De afwikkeling van letselschadeclaims op macroniveau, in: De kosten van het geschil (LSA-bundel 2008), Den Haag: Sdu Uitgevers 2008, p. 133-157, i.h.b. p. 133. Vgl. ook J.M. Barendrecht, Aansprakelijkheid en welzijn, NJB 2002, p. 615. Barendrecht houdt het op 50 cent per euro voor het aansprakelijkheidsrecht en 20 cent voor sociale zekerheid of een schadefonds. Hartlief sluit zich hierbij aan: T. Hartlief, De meerwaarde van het aansprakelijkheidsrecht, in: T. Hartlief \& S. Klosse (red.), Einde van het aansprakelijkheidsrecht, Den Haag: Boom Juridische uitgevers 2003, p. 1-62, i.h.b. p. 25.

84. Vgl. Van de Bunt 2016, p. 213-215.

85. Vgl. ook Van de Bunt 2016, p. 213-215; Engelhard \& Rijnhout 2015, p. 165.

86. Ibid. 
den in het buitengerechtelijk traject dan minder kosten gemaakt door het slachtoffer (en dit zijn kosten die de dader moet vergoeden $)^{87}$ en ook de dader hoeft minder deskundigen in te zetten voor de bepaling van de schade. Maar er kunnen ook besparingen zijn die ten goede komen aan het slachtoffer. In een gerechtelijke procedure krijgt het slachtoffer zijn kosten slechts gedeeltelijk vergoed via de proceskostenveroordeling; wanneer hij minder kosten maakt, hoeft hij minder zelf te betalen. Dat is in zijn voordeel - er blijft dan meer van zijn schadevergoeding over.

De inzichten uit mijn proefschrift belichten met name twee voordelen van normering: een kortere en goedkopere procedure, en als gevolg daarvan een gezonder en tevredener slachtoffer. Die voordelen bieden steun aan de (verdere) ontwikkeling van normering van personenschade. In de volgende paragraaf wordt een mogelijk toekomstperspectief geschetst.

\section{Toekomst: naar all-inbedragen?}

Bij het Schadefonds Geweldsmisdrijven, dat een tegemoetkoming biedt aan slachtoffers die door een geweldsmisdrijf ernstig lichamelijk of psychisch letsel hebben opgelopen, is in 2014 een nieuwe wijze van normering ingevoerd. Slachtoffers krijgen één bedrag als tegemoetkoming voor al hun materiële en immateriële schade. Vormt deze werkwijze de toekomst voor de normering van personenschade?

Het Schadefonds Geweldsmisdrijven heeft de praktijk van het uitbetalen van een vergoeding voor alle verschillende schadeposten, die slachtoffers moesten aantonen door middel van bonnetjes, verklaringen en andere bewijsstukken, in 2014 verlaten naar aanleiding van onderzoek van Mulder onder de slachtoffers. ${ }^{88}$ Uit dat onderzoek bleek dat de tevredenheid van slachtoffers met name afhangt van de snelheid en wijze van afhandeling van hun verzoek en van de mate waarin het ontvangen bedrag overeenkomt met hun verwachtingen. ${ }^{89}$ Daarnaast had het Schadefonds ervaring opgedaan met de toewijzing van all-inbedragen aan slachtoffers van seksueel misbruik in jeugdzorginstellingen. ${ }^{90}$ Die slachtoffers kregen tegemoetkomingen zonder dat zij hoefden aan te tonen wat de

87. Er moeten dan door de vertegenwoordiger van het slachtoffer minder kosten in rekening worden gebracht, of de norm die voor de vergoeding geldt, de PIV-staffel, zou omlaag moeten worden gebracht. Zie PIV-staffel op: stichtingpiv.nl/wp-content/uploads/2015/12/PIV-staffelBGK-2016.pdf.

88. Zo blijkt uit S.D. Lindenbergh, Van bonnetjes naar all-in-tegemoetkomingen, 8 oktober 2014, www.schadefonds.nl. Dit was het onderzoek van J.W.D.E. Mulder, Compensatie na geweld. Wie krijgt er een vergoeding van het Schadefonds Geweldsmisdrijven en wat zijn de effecten van zo'n financiële vergoeding?, Tilburg: Intervict 2009; J.D.W.E. Mulder, Hoe schadevergoeding kan leiden tot gevoelens van erkenning en gerechtigheid. Lessen uit de praktijk van het Schadefonds Geweldsmisdrijven, NJB 2010, p. 293-296; Mulder 2013.

89. Zie Mulder 2010, p. 293-296, 2013, p. 88-90.

90. Het betreft de Tijdelijke regeling uitkeringen seksueel misbruik, Stcrt. 2013, 20303, laatst gewijzigd Stcrt. 2015, 44573 en het Statuut afhandeling van civiele vorderingen tot schadevergoeding seksueel misbruik minderjarigen in instellingen en pleeggezinnen, bijlage bij Kamerstukken II 2012/13, 33435, 12. gevolgen van het misbruik waren in materiële en immateriële zin.

$\mathrm{Nu}$ deelt het Schadefonds Geweldsmisdrijven het letsel van het slachtoffer in aan de hand van een door deskundigen opgestelde letsellijst in één van een zestal categorieën. ${ }^{91}$ Voor elke categorie geldt een vast tegemoetkomingsbedrag: $€ 1000$, $€ 2500$, $€ 5000$, $€ 10.000$, $€ 20.000$ of $€ 35.000$. De categorieen gelden voor zowel lichamelijk als psychisch letsel. Er is een lijst van specifiek fysiek letsel per lichaamsdeel en van psychisch letsel per misdrijf en de daarbij behorende letselcategorieën. ${ }^{92} \mathrm{Bij}$ het Schadefonds is dus een vergaande vorm van normering door standaardbedragen ingevoerd.

Zou zulke normering een aantrekkelijk perspectief zijn voor het begroten van personenschade in de verre toekomst - het overgaan naar standaard all-inbedragen voor verschillende typen letsel? Hoewel dit een bijzonder interessante ontwikkeling is, ligt dit niet voor de hand voor de normering in het aansprakelijkheidsrecht. Het Schadefonds keert slechts tegemoetkomingen uit - een benadering van de werkelijke schade gebeurt daar heel globaal. Dat is ook terug te zien in de hoogte van de uitkeringen. Waar het Schadefonds bedragen uitkeert tussen $€ 0$ en $€ 35.000$ aan slachtoffers die vergelijkbaar zijn met slachtoffers in een (buiten)gerechtelijk letselschadetraject, liggen de vergoedingen voor die laatste slachtoffers op basis van het aansprakelijkheidsrecht grofweg tussen $€ 0$ en $€ 5$ miljoen. ${ }^{93}$ Dat verschil is enorm. Het zou slechts kunnen als er heel veel scenario's zouden worden uitgedacht, die tot heel uiteenlopende en ook hoge schadebedragen kunnen leiden. Ik voorzie dat, ook als dat gebeurt, het lastig zou zijn om daar draagvlak voor te creëren bij zowel slachtoffer- als daderorganisaties - ook al zou het slachtoffer gebaat kunnen zijn bij een veel kortere, minder belastende procedure en de dader bij lagere kosten.

\section{Conclusie}

In dit artikel is geïnventariseerd wat de stand van zaken is bij de begroting van personenschade door normering. Het beeld doemt op van een toenemend belang van de normering van personenschade in de afgelopen vijftien jaar. Een voortrekkersrol heeft daarbij De Letselschade Raad (gehad), maar ook de rechter (en mogelijk ook de wetgever in de toekomst ${ }^{94}$ ) heeft zich niet onbetuigd gelaten. Omdat de hoogte van de schade die slachtoffers van personenschade lijden zo verschillend is, is normering vooral gelegen in het gebruik van standaardmethoden om de schade te berekenen en minder in het hanteren van

91. Vgl. Beleidsbundel 1 juli 2016 van het Schadefonds Geweldsmisdrijven, par. 1.2.3. Deze is te raadplegen via: www.schadefonds.nl.

92. Zie de Letsellijst 1 juli 2016 van het Schadefonds Geweldsmisdrijven. Deze is te raadplegen via: www.schadefonds.nl.

93. Dit bedrag, $€ 5$ miljoen, is ook het maximumbedrag dat verzekerd wordt onder de aansprakelijkheidsverzekering voor particulieren.

94. Als het wetsvoorstel affectieschade (34257) wordt aangenomen. 
standaardbedragen. ${ }^{95}$ Die standaardmethoden kunnen eenvoudig zijn, zoals de berekening van een kilometervergoeding, of complex, zoals de berekening van overlijdensschade, zo heeft de inventarisatie van de huidige praktijk van de normering van personenschade laten zien. Normering, zo blijkt uit onderzoek van de afgelopen jaren, heeft verschillende voordelen. Een voordeel is dat zij leidt tot een kortere procedure, waar vooral het slachtoffer baat bij zal hebben. Het slachtoffer zal hierdoor mogelijk ook eerder herstellen en tevredener zijn over de procedure. De (verzekeraar van de) dader profiteert met name van de lagere kosten van de buitengerechtelijke procedure door normering. ${ }^{96}$ Voor het slachtoffer vallen de kosten van een eventuele gerechtelijke procedure lager uit.

Hoewel een flink aantal schadeposten genormeerd is, geldt dat nog niet voor alle schadeposten. De ontwikkeling die is ingezet, kan dus voortgaan. Voor een aantal schadeposten geldt dat deze verder genormeerd kunnen worden en dat daarvoor al voorwerk is verricht. Van een schadepost als het verlies van arbeidscapaciteit kunnen diverse aspecten worden genormeerd. Een ervan, de rekenrente, is nu voorwerp van onderzoek door een werkgroep van De Letselschade Raad. Ook andere aspecten van het verlies van arbeidscapaciteit, zoals het ontwikkelen van verschillende carrièreperspectieven, zouden op de agenda moeten worden gezet. $\mathrm{Nu}$ er een Denktank Smartengeld is opgericht, behoort ook een breedgedragen richtlijn voor die schadepost tot de mogelijkheden in de nabije toekomst. Voor de normering van affectieschade maakt de wetgever zich sterk. Voorts zouden begrafeniskosten gemakkelijk kunnen worden genormeerd; deze kosten zijn in de praktijk echter gemakkelijk te onderbouwen, omdat de kosten al gemaakt zijn. De nood is daar niet zo hoog.

$\mathrm{Na}$ het bekijken van de stand van zaken en de mogelijkheden tot uitbreiding van normering van personenschade is de ontwikkeling van de all-inbedragen voor zowel materiële als immateriële schade van het Schadefonds Geweldsmisdrijven beschreven. Er bestaat zeker een groot voordeel voor het slachtoffer in termen van een vlottere afwikkeling. Maar de stap van zulke normering door het Schadefonds naar normering van personenschade is heel erg groot. Het zal heel erg lastig zijn om draagvlak voor een benadering met all-inbedragen te creëren bij slachtoffer- en daderorganisaties - er moet dan echt sprake van consensus zijn. Zo ver is het voorlopig nog lang niet: laten we eerst kijken of zo veel mogelijk standaardmethoden om de schade te berekenen uitgedacht kunnen worden.

95. Zo blijft er eventueel ook ruimte voor een herstelgerichte benadering. Deze benadering is op dit moment nog in ontwikkeling. Vgl. G. van Dijck, Naar een nieuw schadevereiste in het aansprakelijkheidsrecht, NJB 2016, p. 1608-1606.

96. Dat moet de (aansprakelijkheidsverzekeraar van de) dader dan wel weten te verzilveren. Anders komt het voordeel toe aan de vertegenwoordiger van het slachtoffer. 